\title{
The Use of Canal Lining Available Materials and Its Comparative Study
}

\author{
Pradeep Sahu ${ }^{1}$, A. K.Saxena ${ }^{2}$, Dr. M. K.Travadi ${ }^{3}$ \\ ${ }^{I}$ (M.E. Student, civil Engineering Department MITS, Gwalior (M.P), India \\ ${ }_{2}^{2}$ (Associate Professor, civil Engineering Department MITS, Gwalior (M.P), India \\ ${ }^{3}$ (Associate Professor, civil Engineering Department MITS, Gwalior (M.P), India
}

\begin{abstract}
The purpose of this study is to produce a comparative study of irrigation canal lining by the use of excising materials. This study reveals why irrigation canals lining and describes a number of various lining and there analysis. Requirement of line should be supported an analysis like water conservation, cut backed water work and suitable method of excavation, lower operation and maintenance, structural safety and long life. There are various materials which are adopting concrete lining, mineral lining, brick lining, asphaltic lining, and geo membranes lining. However in our country as per environmental condition mostly tile and cement concrete lining are popular. These kind of lining such as long life or effective in price and most satisfactory for all kind of locations. Life cycle cost of lining for financial assessment, Cut back maintenance and operation price of canal is also effectively studied.
\end{abstract}

Keyword: Reduce damage, highly saving in water, Increases efficiency of water, Reduce cost.

\section{INTRODUCTION}

The irrigation has been practiced from the time immemorial and so has been building of irrigation canals, but is not only since last century that canals have been designed on more or less scientific basis. The conveyance and distribution of water are an integral part of any irrigational project. Irrigation system should be built in such a way that they operate in maximum efficiency. Many surface irrigation projects in most developing countries are performed at levels much below their potential in terms of crop productivity, water dependability, equity and efficiency.

The efficiency of the conveyance and distribution system, that is the transport of water at minimum cost and with minimum water loss, essentially affects the total economy of an irrigation project. Seepage losses may be and have been satisfactorily reduced through the installation of relatively impervious linings or by special treatment of canal sections. Determination of the need of lining should be based on an analysis of benefit such as water conservation, reduced water logging of lower drainage requirements, reduced excavation and right of way cost, lower operation and maintenance costs and structural safety .It is very important to store, transport and use the available water without under loss through evaporation or leakage. Lining irrigation canals to prevent seepage losses, which average 40 percent of the water transported in unlined canals, is justified on a purely economic basis [1]. Therefore the loss of this valuable water cannot be tolerated. Lining of an irrigation canal is justified economically when its cost can be repaid in terms of Benefits derived during the life of the lining. Some of the most important tangible benefits resulting from lining irrigation canals those that can be evaluated with some accuracy are saving of water that would otherwise be lost though seepage, reclamation of water logged lands, lower maintenance and economies of canal lining operation cost, and right of way requirements, etc. Some additional benefits from lining canals, such as prevention of bank erosion and better control and more uniform distribution of water, are difficult to evaluate from a monetary standpoint, but should be given consideration when the value of lining is being appraised. In India different type of canal lining materials are commonly used namely brick, concrete tile, cement concrete, membrane etc. The materials are selected as per the following criteria such as. Discharge, Soil condition, Material availability, Labour availability, Climate conditions, Time of completion etc. Out of the above mentioned materials, concrete tile lining and cement concrete lining are very commonly used worldwide.

Kautiyliya Arthasastra (4th century B.C.) gives copious regarding construction of dams, canal, management of canal water levying of tax, the irrigation works used to be construction privately by individuals or co- operatively. If the work is large, king was also lending his hand for its construction. There were about 550 weirs across in madras, each connected with a series of tanks. And 10,000 tanks were in disrepair [2]. The area irrigated from these tanks exceeded 1.415 million hectares. Smith stated that the length of embankments of tanks may be taken on average of $0.85 \mathrm{kms}$. The numbers of masonry works as sluices for irrigation, waste water weir could be six per tank. This shows that the total length of embankments of these 53,000 tanks would be $57,790 \mathrm{kms}$. This is sufficient to put a girdle round the globe not less than $1.80 \mathrm{~m}$ thick and three million separate masonry works. Masonry or earth "Bandharas about 200of which were in operation (in 19th century) and many 
were in ruined state, were constructed by Indian Engineers on rock foundation. They exist on every perennial stream of Dhule district. Most of these bandanas consist of solid masonry weirs. The above description of irrigation works in India before the advent of the British gives the idea of the vastness of system and it could be stated that anything comparable of it did not exist in any other part of world. Tank irrigation as described above was practiced all over India except in the provinces of Punjab and Sind. Irrigation by inundation canals was practiced in these provinces. The inhabitants on banks of river Indus learnt to excavate small channels through the higher land on the immediate bank of stream of irrigation lands [3]. This system of inundation canals was used from unknown ages by which the rising water of Indus was tapped and used to irrigate fertile lands laying in the comparative rainless plains of valley the examples of such canals are the western and eastern Yamuna canals on the Yamuna and the Hasli canal on the Ravi. These were dug during the 14th and 18th centuries respectively. The lining type used in India is shown in fig $\mathbf{1}$ it is shown that cast in situ and cement concrete lining is most popularly adopted.

\section{CASE STUDY}

In this paper Datia irrigation canal lining is taken as a case study. Calculation data show in table 1.Existing and alternative lining types are compared with respect to life cycle and economically viability.

Table. 1 Datia Irrigation Canal between RD14610m To16050m.

\begin{tabular}{|c|c|c|}
\hline 1 & Name of work & Construction of tile. lining \& cast in site lining of Datia irrigation \\
\hline 2 & $\begin{array}{l}\text { Estimated } \\
\text { Amount }\end{array}$ & Amount of lining cost differ as per selecting type of lining \\
\hline 3 & Necessities & $\begin{array}{l}\text { Datia Irrigation Canal is one of the most important canal of Rajghat Canal system having } 0 \\
\text { to } 62.13 \mathrm{~km} \text { Length, design discharge } 62.70 \text { cumecs, and } 57683 \text { ha, command area in district } \\
\text { Datia (M.P.) } \\
\text { The reach of Datia Irrigation Canal between RD } 14610 \mathrm{~m} \text { to } 16050 \mathrm{~m} \text { having forest area } \\
\text { therefore in the period of construction Earth work and lining work not completed in this } \\
\text { reach there are piping, breaches, have seepage was occurred last five year respectively due } \\
\text { to these cusses Rabi irrigation was badly affected during last season. The Chief Engineer Raj } \\
\text { ghat Canal Project and Executive Engineer, Rajghat Distributor Division No.9 Datia has } \\
\text { directed to take immediate action for complete Canal Section including Lining work. }\end{array}$ \\
\hline $\begin{array}{l}4(a \\
)\end{array}$ & $\begin{array}{l}\text { Provision for tile } \\
\text { lining }\end{array}$ & $\begin{array}{l}\text { The Main Cause of come out after observations during running of D.I.C. was seepage from } \\
\text { canal Bank, accordingly the Cast in situ lining providing C.C. } 1: 2: 4100 \mathrm{~mm} \text { thick in bed and } \\
60 \mathrm{~mm} \text { thick pec tiles of } 500 \mathrm{~mm} \text { x } 500 \mathrm{~mm} \text { in M-10 Concrete over } 15 \mathrm{~mm} \text { thick cement mortar } \\
\text { in side slopes are proposed to prevent to seepage and for safe running of canal with E/W on } \\
\text { outer slopes of D.I.C. to cover the H.G. Line } 4: 1 \text { by } 0.60 \mathrm{M} \text {. }\end{array}$ \\
\hline $\begin{array}{l}4(b \\
)\end{array}$ & $\begin{array}{l}\text { Provision for } \\
\text { C.C. } \\
\text { lining }\end{array}$ & $\begin{array}{l}\text { The Main Cause of come out after observations during running of D.I.C. was seepage from } \\
\text { canal Bank, accordingly the Cast in situ lining providing C.C.1:2:4 } 100 \mathrm{~mm} \text { thick in bed and } \\
75 \mathrm{~mm} \text { thick in side slopes are proposed to prevent to seepage and for safe running of canal } \\
\text { with E/W on outer slopes of D.I.C. to cover the H.G. Line } 4: 1 \text { by } 0.60 \mathrm{M} \text {. }\end{array}$ \\
\hline 5 & Rate & The rates are as per U.S.R. Enforced from 01-02-2009 \\
\hline 6 & Specification & The Specification is proposed as per M.P. Water Resources Deptt. Issued at time to time. \\
\hline 7 & $\begin{array}{l}\text { Detail abstract } \\
\text { and } \\
\text { estimate }\end{array}$ & Provide in anx-iii \& iv \\
\hline 8 & $\begin{array}{l}\text { Material } \\
\text { consumption } \\
\text { statement }\end{array}$ & Provide in anx-v \\
\hline
\end{tabular}

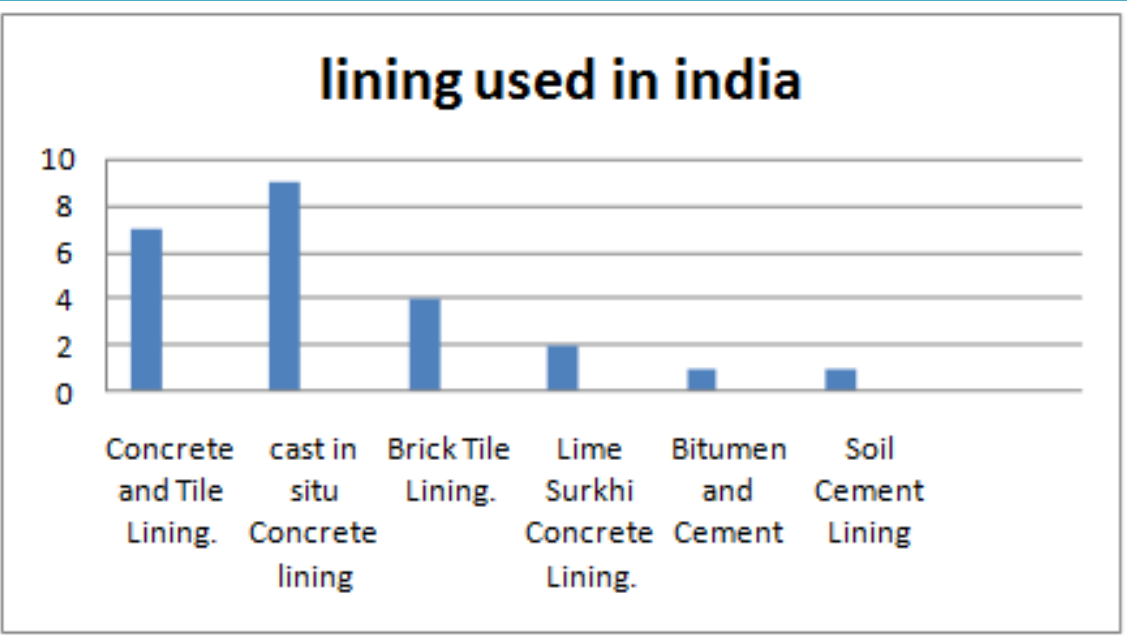

Fig. 1 Lining Types Used in India 


\section{RESULT AND DISCUSSION OF CANAL LINING}

Comparison of the two different comparing estimated annual costs of types of lining cost show in the Table no 2.The following work illustrates calculate and compare annual costs and also in graphical form show in fig.2.

Table.2 for Comparing Estimated Annual Costs of Types of Lining

\begin{tabular}{|c|c|c|c|}
\hline S.No. & Type of work & \multicolumn{2}{c|}{ Lined canal } \\
\hline & & C.C. Lining & Tile Lining \\
\hline $\mathbf{1}$ & Excavating, filling, compacting and trimming, & 77310 & 77310 \\
\hline $\mathbf{2}$ & $\begin{array}{c}\text { Checks, turnouts, bridges and other necessary Structures. } \\
\text { ( average cost of each std. @ 120000) no of 5 std }\end{array}$ & $6,000,000$ & $6,000,000$ \\
\hline $\mathbf{3}$ & Total lining cost (as per detailed estimatision ) & 10849987 & 12033729.75 \\
\hline $\mathbf{4}$ & Incidental construction (lum sum as per sor) & $1,000,000$ & $1,000,000$ \\
\hline $\mathbf{5}$ & Total construction cost: $1+2+3+4$ & 17927297 & 19111039.75 \\
\hline $\mathbf{6}$ & Life expectancy: & 50 & 30 \\
\hline $\mathbf{7}$ & salvage value at life expectancy & $25 \%$ of lining cost, & $15 \%$ of lining cost, \\
\hline & & 4481824.25 & 2866655.963 \\
\hline $\mathbf{8}$ & Total depreciation during life: 5-7 & 13445472.75 & 16244383.79 \\
\hline $\mathbf{9}$ & Annual depreciation charge: $8 / 6$ & 268909.455 & 541479.4596 \\
\hline $\mathbf{1 0}$ & Annual interest charge:( $5+7) / 2$ ) interest rate & 560228.0313 & 549442.3928 \\
\hline $\mathbf{1 1}$ & Annual maintenance charge & 244190.3 & 695655.36 \\
\hline & Total annual cost $:$ 9+10+11 & $\mathbf{1 0 7 3 3 2 7 . 7 8 6}$ & $\mathbf{1 7 8 6 5 7 7 . 2 1 2}$ \\
\hline
\end{tabular}

In this study concrete lining and tile lining are commonly used in India and discussed fairly and a compression with respect too economically and durability is shown in table 3. Canal linings are expensive. In usual terrain a lined canal may cost twice as much as an equivalent unlined earth canal; however, in rough terrain a lined canal may be less expensive in first cost than an unlined canal because of savings in excavation and structures in the smaller sections of a lined canal. In view of the probable increased first cost, a decision to use lining needs justification. It may be based on intangible benefits, long-range tangible benefits, or a combination of tangible and intangible benefits. In addition to a possible saving in construction costs, the more common benefits derived from canal lining are

(1) A saving in water,

(2) Reduced damage to lowlands from seepage or reduced drainage cost,

(3) Greater safety, and

(4) Reduced operation and Maintenance costs.

Table 3 Compare Study of Tile and Concrete Lining

\begin{tabular}{|c|c|}
\hline Tile lining & C.C lining \\
\hline $\begin{array}{l}\text { Curing of tile better become they construct in } \\
\text { Yard place. }\end{array}$ & $\begin{array}{l}\text { Market cost low and strength are more than Tile } \\
\text { lining. }\end{array}$ \\
\hline $\begin{array}{l}\text { Replacing of tile not easy, damage of tile in } \\
\text { Case settlement. } \\
\text { Handling and placing or transportation cost so } \\
\text { much high, because bear and tear losses higher } \\
\text { or manicure quantity not more for economical. }\end{array}$ & $\begin{array}{l}\text { Replacing in cement concrete lining easy on Site } \\
\text { and desired quantity. } \\
\text { That paste / material prepare on site. As per } \\
\text { Requirement. }\end{array}$ \\
\hline $\begin{array}{l}\text { Proper thickness govern easy but filling not } \\
\text { possible. }\end{array}$ & $\begin{array}{l}\text { Proper thickness govern by calculate adjoining level } \\
\text { but filling easily possible and in case of piping } \\
\text { another condition grouting very easily Done. }\end{array}$ \\
\hline $\begin{array}{l}\text { Thickness more for same strength govern by } \\
\text { CC. } \\
\text { ( due to small size and number of joints) }\end{array}$ & $\begin{array}{l}\text { In comparison of tile lining Thickness of Cement } \\
\text { Concrete slim }\end{array}$ \\
\hline $\begin{array}{l}\text { In this lining joint and groove are more so } \\
\text { coefficient of friction high }\end{array}$ & $\begin{array}{l}\text { In this lining joint and groove in proper /controlled } \\
\text { distance. So coefficient of friction Low. }\end{array}$ \\
\hline
\end{tabular}




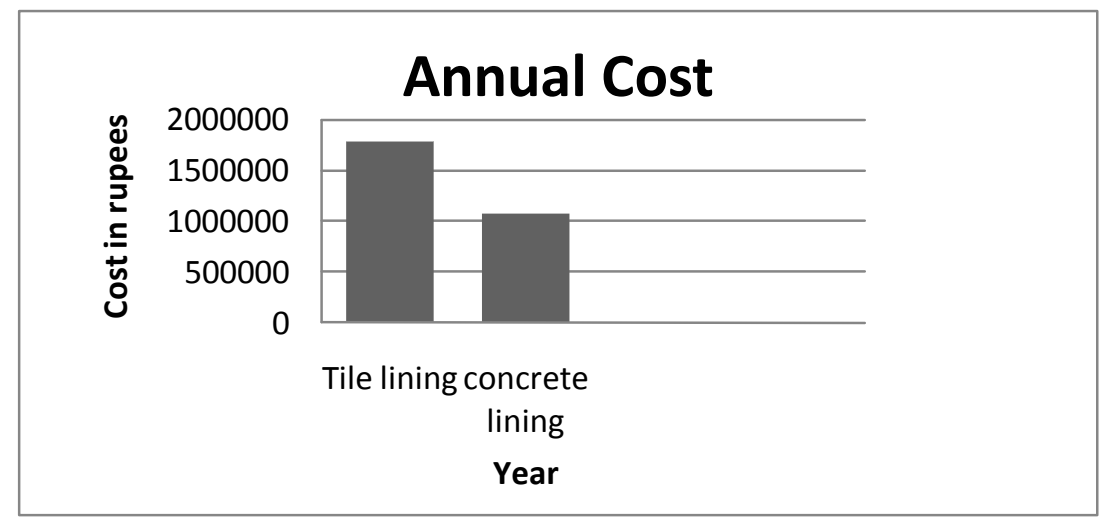

Fig.2 Compares the Annual Cost of Tile Lining With Concrete Lining

\section{LIFE CYCLES AND ECONOMIC ANALYSIS}

The importance of including canal lining (or provision for future lining) in the original Construction plans and designs of an irrigation project, provided studies have demonstrated its economic feasibility, It is only during the planning and designing stages that full advantage can be taken of the many benefits of the installation of a canal lining. When lining is included in the original plans and designs, the cost of the lining might be justified in consideration of reduced storage and diversion requirements, smaller canal sections, smaller and possibly fewer canal structures, reduction of pumping costs where pumping is necessary, and a possible reduction in the right-of-way requirements. Seepage losses from canals and laterals represent a loss to the intended user not only of value able irrigation water, but also a considerable loss in the costs of additional construction from which no return is received on the investment. Storage reservoirs and dams must be constructed of sufficient size to impound not only the useful water but also the water that will be diverted in transit by seepage from the canals. Reduction of the loss of water from a canal may be economically important when the water supply available at the head of the canal is limited or when all of the water has to be pumped. Since the amount of leakage and the unit value of the lost water are of primary importance, a measurement estimate of the amount of leakage must be made before the need for lining can be definitely as certainness. The cost of constructing, operating, and maintaining a large or lengthy drainage system for the sole purpose of picking up main canal seepage losses may be materially greater than the cost of lining the canal to prevent those water losses, For example, if a lining is being considered for a canal, either new construction or as an addition to existing facilities, the economic studies for using a hard-surface type lining can properly include benefits anticipated from reduced costs of weed control, less danger from burrowing rodents, less silt removal, and other conditions which a rigid, high-quality lining will provide. On the other hand, the economic studies for an earth lining or buried membrane cannot include many of these factors and must rely primarily on the value of seepage prevention for justification. The type of lining, therefore, determines some of the factors which may be considered in the economic analysis. One of the largest items of recurring maintenance costs on many canal systems is weed control and the removal of weeds and water-loving plants from the canal section. Such as, Quality, hard-surface linings as concrete, shot create, and to a less extent, asphaltic concrete, being practically impenetrable by weeds and water-loving plants, would greatly reduce the cost of weed control and removal from the canals. It is possible to obtain rather accurately the construction cost of a canal lining. The annual savings or benefits to be derived from lining, however, are more difficult to evaluate and must include an estimate of the difference in annual maintenance cost between a lined and an unlined canal. Unfortunately, maintenance cost data frequently are inconclusive and incomplete so far as being explicit as to just what the costs include. On water-user-operated projects (including most projects constructed by the Bureau), time and personnel are seldom available for making a careful breakdown of individual maintenance cost items. The costs may be for lining repair only, or they may include the cost of cleaning silt, sand, and other debris from the canal perimeter, etc. Separation of costs for these various maintenance activities is difficult, from most records received. Good maintenance cost data should include the expense necessary to keep the channels in the condition they were in when transferred from a construction to an operation and maintenance status. Costs incurred for supplemental construction and other items of expense which are properly classed as improvements should be considered as completion of construction rather than maintenance. Weed control expense should preferably include only that expense incurred for control of aquatic and land type weeds", the canal or lateral prism. However, it is difficult to segregate the cost for control of land type weeds on right-of-way, roads, and outside banks, the total cost for land type weeds is usually included in the maintenance data. This latter cost, although common to all lined or unlined canals, may vary considerably because of seepage through the banks of unlined or ineffectively lined canals, which may stimulate the growth of weeds outside of the canal prism. Except for repairs that may be 
necessary to correct faults that develop soon after construction, lining maintenance costs are usually rather nominal. However, ultimately a cleaning job or an extensive repair becomes necessary and the cost of this work may be appreciable, even approaching in some instances the original construction cost. For this reason cost records must cover long periods to be representative. In comparing costs between projects, factors such as climate, period of operation, type of terrain, and service conditions are generally so variable that suitable parallels do not exist. Other variable factors include water velocity, capacity, available construction materials, thickness and types of linings, side slopes, and effectiveness of drainage, leakage, rodents, cattle, wind, and stability of soils in adjoining fields. All of these factors have a bearing on maintenance costs, and many are difficult to evaluate. In view of the number and variability of the factors enumerated, Though comparison of costs between projects is generally not practicable, operating and maintenance costs for lined and unlined canals can sometimes be secured from cost data on existing canals on the same project or on projects operating under similar climatic, geographical, and agricultural conditions. One project justified lining and the use of buried concrete pipe in lieu of lining on the basis of just such a study, proving that weed control costs, primarily, would justify the use of linings and buried pipe The type of lining to be used must also be considered from the standpoint of useful life considering maintenance cost and eventual replacement cost. The lower cost type linings constructed by the Bureau have been in service for only a relatively short period of time, linings of urines forced Portland cement concrete, buried asphalt membranes, and thick compacted earth having been in service only since 1948-50. Replacement of only a very few of the linings of the types mentioned is contemplated in the near future. There is reason to believe that most of the linings will be effective for many more years; but an assumption must be made in computing the maintenance cost or replacement cost, if an annual cost for feasibility estimates is to be prepared. Construction costs, the value of water, drainage problems, protection from failure, and increased capacity are factors that can usually be evaluated with reasonable accuracy. Formulas proposed for determining the feasibility and practicability of lining an unlined canal have included these factors, and also factors which consider the life of the lining and its maintenance. As has been pointed out previously, however, these latter type factors must be assumptions based upon limited information. Further, for proposed linings for new canals, the formulas should properly include factors to reflect such items as reduced storage and diversion requirements, smaller and fewer canal structures, and smaller canal sections that would result from lining. As these factors are all difficult if not impossible to evaluate with accuracy, the formulas have generally proved of doubtful value, and proof of feasibility by the use of formulas is not attempted by the Bureau. Rather, consideration is given to the individual and specific factors inherent in a given project or area to be benefited.

\section{1: Life cycle consideration}

Various lining type may be applicable to any one situation and the final lining type selection should be based on following consideration.

1. Soil condition and its property

2. Importance of irrigation water requirement and land value.

3. Local ability of material

4. Availability and conditions of labor,

5. Latest machinery equipment

\section{2: The Amount of Tangible and Non-Tangible Benefit From Lining}

$>$ Time and material estimation

$>$ Personnel, equipment and material cost estimation

$>$ Total construction cost estimation

$>$ Annual maintenance requirement and cost estimation

$>$ Total annual canal costs

$>$ Estimation of potential benefit

\section{CONCLUSION}

In this study mainly fuscous on the detail of life cycle on the deferent type of lining and its durability, compare cement concrete lining and tile lining. According to analysis of thesis topic "economics of canal lining" concrete lining is more suitable then the tile lining. Cost analysis of the topic Cement concrete lining more cost effective then other types of lining methods. In Indian scenario and resultant of the study shows that we can save and evolve new methodology of lining (Concrete \& tile) So that we can reduce estimating cost of lining project on urban \& rural level lining . 


\section{REFERENCES}

[1]. Dr. B.L.Deopura did his doctorate from IIT Kanpur. He joined IIT Delhi as a faculty in 1974. He spent about a year at University of Massachusetts, Amherst in 1979 and also at US Air Force Materials Laboratory, Dayton Ohio in 1985. He has to his credit a large number of publications, conference presentations and chapters in books. His contributions on developments of water lining material are of major significance, with a major impact on water conservation.

[2]. B. R. Chahar, Asso Professor, Dept of Civil Engg, IIT Delhi. Earned PhD degree on "Optimal Design ofChannel Sections considering Seepage and Evaporation Losses” from IIT Roorkee and MTech degree in Water Resources Engg from IIT Kharagpur. His current areas of research include Seepage, Subsurface drainage,Urban drainage, Groundwater modeling, Channel design and Numerical methods. He is recipient of several

[3]. GUIDELINES FOR PLANNING OF PARALLEL CANALS -Central Water Commission Ministry of Water Resources Government of India.

[4]. Dr.M.R.Kabir- Professor and Head, Department of Civil Engineering University of Asia Pacific (UAP), Dhaka. Department Of The Interior Bureau Of Reclamation office of chief engineer denver, colorado canals and related structure Irrigation Engineering Principles( CE IIT, Kharagpur ) - Canal Systems for Major and Medium Irrigation Schemes.

[5]. Syed Zafar Syed Muzaffar, S.L. Atmapoojya, D.K. Agarwal, 2012, vol.2 issue 1, "Minimum Lining Cost of Trapezoidal Round Cornered Section Canal” International Journal of Advances in Engineering \& Technology” (IJAET) pp 433-436.

[6]. Water resource department of Madhya Pradesh-Indian standard cods \& specifications or guidelines.

[7]. R.S. Varshney, S.C. Gupta, "Theory and design of irrigation structures" Roorkee, India, Nem Chand \&Bros., 1979.

[8]. R.L.Gupta "Irrigation and water power engineering" Lakshmi Publications Pvt Ltd New Delhi-2009. 